\title{
Fiscal Consequences of Electoral Institutions
}

\section{Citation}

Christopher R. Berry \& Jacob Gersen, Fiscal Consequences of Electoral Institutions, 52 J.L. \& Econ. 469 (2009).

\section{Published Version}

http://www.jstor.org/stable/pdfplus/10.1086/595764.pdf

\section{Permanent link}

http://nrs.harvard.edu/urn-3:HUL.InstRepos:10913982

\section{Terms of Use}

This article was downloaded from Harvard University's DASH repository, and is made available under the terms and conditions applicable to Open Access Policy Articles, as set forth at http:// nrs.harvard.edu/urn-3:HUL.InstRepos:dash.current.terms-of-use\#OAP

\section{Share Your Story}

The Harvard community has made this article openly available.

Please share how this access benefits you. Submit a story.

Accessibility 


\section{CHICAGO JOURNALS}

The University of Chicago

The Booth School of Business of the University of Chicago

The University of Chicago Law School

Fiscal Consequences of Electoral Institutions

Author(s): Christopher R. Berry and Jacob E. Gersen

Source: Journal of Law and Economics, Vol. 52, No. 3 (August 2009), pp. 469-495

Published by: The University of Chicago Press for The Booth School of Business of the University of Chicago and The University of Chicago Law School

Stable URL: http://www.jstor.org/stable/10.1086/595764

Accessed: 02/08/2013 14:48

Your use of the JSTOR archive indicates your acceptance of the Terms \& Conditions of Use, available at http://www.jstor.org/page/info/about/policies/terms.jsp

JSTOR is a not-for-profit service that helps scholars, researchers, and students discover, use, and build upon a wide range of content in a trusted digital archive. We use information technology and tools to increase productivity and facilitate new forms of scholarship. For more information about JSTOR, please contact support@ jstor.org. 


\title{
Fiscal Consequences of Electoral Institutions
}

\author{
Christopher R. Berry University of Chicago \\ Jacob E. Gersen University of Chicago
}

\begin{abstract}
There are more than 500,000 elected local government officials in the United States. The most electorally dense county has more than 20 times the average number of elected officials per capita. This paper offers the first systematic investigation of the link between electoral density and fiscal outcomes. Electoral density presents a tradeoff between accountability and monitoring costs. Increasing the number of specialized elected offices promotes issue unbundling, reducing slack between citizen preferences and government policy; but the costs of monitoring a larger number of officials may offset these benefits, producing greater latitude for politicians to pursue their own goals at the expense of citizen interests. We predict diminishing returns to electoral density and a U-shaped relationship between the number of elected local officials and government fidelity to citizen preferences. We find that public sector size decreases with electoral density up to a point, beyond which budgets grow as more officials are added.
\end{abstract}

\section{Introduction}

Perhaps the most fundamental question for a constitutional democracy is how to structure the relationship between the public and politicians. However, empirical evidence about some extremely basic facets of the electoral system is lacking. First and foremost among these is how the number and type of elected officials in a jurisdiction affect public policy. Elections may be the cornerstone of democracy, but without a rigorous understanding of how the number of elected offices and the scope of electoral jurisdictions affect policy, critical questions in democratic theory will go unanswered.

Indeed, the ability of citizens in the United States to select their governing officials varies enormously from place to place. For instance, Lake County, Illinois, is governed by 1,125 local officeholders, whereas the similarly populated

We are grateful for very useful comments from Avinash Dixit, Nicole Garnett, Eric Helland, Rick Hills, Anup Malani, Roger Myerson, and Eric Posner. Thanks to Peter Wilson for excellent research assistance. Financial support was provided by the John M. Olin Foundation, the Lynde and Harry Bradley Foundation, the Stigler Center, the Smith Richardson Foundation, and the Robert B. Roesing Faculty Fund.

[Journal of Law and Economics, vol. 52 (August 2009)]

(C) 2009 by The University of Chicago. All rights reserved. 0022-2186/2009/5203-0019\$10.00 
Mecklenburg County, North Carolina, has only 67 elected officials. This paper explores how variation in the structure of local electoral institutions exacerbates or mitigates agency problems between voters and elected officials in local fiscal behavior. Specifically, we model the taxing and spending of local governments as a function of the number and nature of elected officials within a jurisdiction. Our central claim is that the addition of elected officials often unbundles policy issues so as to produce greater voter control over elected officials. However, because monitoring elected officials entails costs, having too many elected officials in a jurisdiction can sometimes worsen agency problems and produce greater slack in the relationship between voters and politicians. This dynamic can produce a $U$-shaped relationship between the number of elected officials in an area and fidelity to voter preferences.

The theory and data capture essential elements of the relationship between electoral institutions and public policy not previously emphasized or analyzed. For example, the existing literature contains conflicting views of the relationship between the size or structure of government and the level of taxing and spending. Different theoretical and empirical camps insist that the relationship is positive, negative, or nonexistent. This disagreement results, in part, from a lack of precision and nuance about the different types of elected officials. Electoral institutions come in many shapes and sizes. There are more than 500,000 elected officials in the United States, or roughly one representative for every 600 inhabitants. The vast majority of these elected officials-96 percent-are in local governments. In addition to electing members of local governing bodies, such as city councils, county commissions, and school boards, voters choose myriad officials in the local executive and judicial branches, including mayors, judges, sheriffs, and treasurers, to name only a few. The relationship between electoral structures and local policy making has broad implications for the practice of democracy at all levels of government.

\section{Background and Theory}

In textbook theories of democracy, elections ensure that politicians' behavior and public policy are consistent with public preferences (Dahl 1989; Sen 1983). This idealized view of elections, however, has long since faltered for many reasons discussed extensively in the literature (see, for example, Persson and Tabellini 2000). ${ }^{1}$ Perhaps most important, the relationship between citizen and legislator is riddled with agency problems. Elections provide a mechanism for voters to select representatives who are more likely to take desirable actions (Gordon, Huber, and Landa 2007; Fearon 1999; Zaller 1992), to sanction legislators who fail to enact policy consistent with voter preferences (Austen-Smith and Banks 1989; Barro 1973; Ferejohn 1986), or both (Ashworth 2005; Ashworth and Bueno

\footnotetext{
${ }^{1}$ The whole notion of popular will might be either incoherent or nonexistent (Campbell et al. 1960; Riker 1982; Zaller 1992).
} 
de Mesquita 2007; Banks and Sundaram 1998, 1993). Participating in elections, however, is costly to voters: voters must collect the requisite information to select, reward, or sanction elected officials appropriately and then turn out at the polls on election day. As such, variation in the electoral structures within and across jurisdictions will affect both the extent of slack in politics and the costs of political participation.

This paper emphasizes one significant, but poorly understood, source of variation: the number of elected officials. Increasing the number of elected officials improves the ability of voters to sanction politicians by unbundling issues into specialized domains (Besley and Coate 2001, 2003). Elections are a crude mechanism for selecting or sanctioning officials when the official is responsible for multiple policy issues but the citizen has only one vote. Unbundling an issue by creating a specialized elected office to govern it enables voters to better ensure implementation of their preferred policy outcome on that issue (Besley and Coate 2003). ${ }^{2}$ We build on the issue-unbundling framework by linking it to the number of elected officials and integrating a theoretical and empirical focus on attendant unbundling costs. In this applied context, increasing the number of elected officials makes monitoring politicians more costly for voters. Depending on how these countervailing forces of accountability benefits and monitoring costs offset one another, increasing the number of elected officials may either increase or decrease the extent of aggregate slack in the relationship between voters and politicians; unbundling reduces slack, but the attendant monitoring costs for voters may undermine this effect. ${ }^{3}$

Electoral monitoring costs are a function of the number of policy domains and the number of elected officials. First, a citizen must determine whether policy in each dimension has been set to a desirable level or, more generally, whether a "good" policy or a "bad" policy has been enacted. Second, for each elected office, the citizen must be able to identify the incumbent and assess his or her ability or responsibility for a particular service or services. On most ballots, citizens see a list of offices and a list of names for each office. The ballot may not identify the incumbent, and in most cases it does not even list a political party affiliation. ${ }^{4}$ At a minimum, a voter must be able to identify the incumbent for each office and match the incumbent to an assessment of the services performed by the office in question. Where there is only one general purpose office, all services can be attributed to one official. The voter needs only to know which

\footnotetext{
${ }^{2}$ Besley and Coate (2003) provide empirical support for their issue-unbundling argument by contrasting elected and appointed utility regulators. Using panel data for U.S. states, they find that elected regulators systematically enact more consumer-friendly policies than do appointed regulators. They do not, however, consider monitoring costs associated with issue unbundling, nor do they explore the implications of unbundling more than one office.

${ }^{3}$ This question is related to important work on the optimal number of governments and related implications for negotiation among electoral institutions (Cooter 2000, pp. 101-25). It also relates to Maskin and Tirole (2004), which focuses on when authority should be given to elected officials and nonaccountable officials, such as judges.

${ }^{4}$ About three-quarters of local elections are nonpartisan (Renner 1999).
} 
candidate is the incumbent and to form an overall assessment of the incumbent's performance, but where there are many offices, the task becomes considerably more challenging. It is not unusual to find several dozen elected offices on a ballot. In these cases, the extent of unbundling and the potential costs of participation are quite significant. In the discussion that follows, the term "monitoring costs" refers to the total effort required to evaluate all services in a jurisdiction and match them to the relevant incumbent officials.

Because issue unbundling via specialized elected offices increases the costs of voting, selective participation may also result. That is, voters with the strongest preferences about the given policy dimension are the ones most likely to bear these increasing costs of participating in specific elections (Berry 2009; Moe 2006; Dunne, Reed, and Wilbanks 1997). Voters with little at stake may rationally focus their limited political attention elsewhere, not voting in some elections on the ballot. Put differently, political participation may be increasingly selective as the extent of unbundling increases, and interest groups will tend to dominate unbundled elections. Because most interest groups want more, rather than less, government spending on the policies they care about, ${ }^{5}$ the addition of elected officials may lead to more majority-friendly policies up to a point because the marginal benefits of unbundling are greater than the marginal costs of monitoring. However, at some point, marginal monitoring costs may exceed marginal unbundling benefits, bringing policy closer to minoritarian preferences. If marginal unbundling benefits decrease with the number of officials and marginal monitoring costs increase, then the overall relationship between the number of officials and policy outcomes should exhibit diminishing returns. At some point, marginal monitoring costs may even outweigh marginal unbundling benefits, potentially resulting in a $U$-shaped relationship between the number of elected officials and government spending. Whether this or any other nonlinear shape results is, of course, an empirical question. If electoral institutions were optimally unbundled, the positively sloped side of the $U$ shape would never be realized in practice. $^{6}$

The remainder of the paper explores these ideas in the context of local fiscal policy. Using a mixture of parametric and semiparametric methods, we estimate the relationship between the number of elected offices in a political jurisdiction and the fiscal behavior of local governments. We find evidence that some unbundling produces less spending but that the marginal effect is decreasing: jurisdictions can have too much unbundling, which increases spending, and, by assumption, slack, rather than decreasing it. Even if one resists the theoretical

\footnotetext{
${ }^{5}$ Although there are certain taxpayer groups that promote smaller government overall, we are aware of relatively few groups that fight for lower provision of services in particular policy areas, such as education or policing.

${ }^{6}$ Note too that we have said nothing about the welfare consequences of issue unbundling. The welfare consequences of issue unbundling parallel those of logrolling in legislatures. A logroll may be welfare enhancing even if a majority of legislators opposes each element of the logroll dimension by dimension.
} 
account of the dynamic between voters and legislators specified above, the empirical analysis fills a major void in the existing political economy literature on democratic governance.

\section{Related Literature}

Although the relationship between the number of elected offices and fiscal policy has not been studied, other literatures have explored how the size of governing institutions affects spending. For example, a robust literature predicts that legislative bodies with more members will tend to overspend. Weingast, Shepsle, and Johnsen (1981) show that, in a legislature with a norm of universalism, districted elections, and general taxation authority, the scale of budget projects increases as the number of districts and, therefore, legislators grows. This effect has come to be known as the "law of $1 / n$," which summarizes the share of tax costs internalized by any single district as the legislature grows. These models essentially treat the tax base as a common-pool resource, which produces standard problems of overextraction. ${ }^{7}$ The model was developed in the context of the U.S. Congress, but its empirical support has come primarily from studies of other legislative bodies. ${ }^{8}$ For example, Gilligan and Matsusaka (1995) show that state-level expenditures are positively related to the number of seats in a state legislature, which they interpret as supporting the hypothesis that increasing the number of elected officials leads to more spending than citizens would like. At the local level, Baqir (2002) finds that jurisdictions with more city council districts (more elected officials on the city council) spend more. Langbein, Crewson, and Brasher (1996) also find that per capita expenditures are positively related to the number of elected members of the city council (in a sample of cities with a council-manager form of government and a weak mayor). Similarly, Dalenberg and Duffy-Deno (1991) argue that cities with ward elections tend to spend more than cities with at-large election systems, which they link to the problem of concentrated benefits and diffuse costs that underlies the law of $1 / n$.

Other political institutions, such as direct citizen initiatives or referenda, can also reduce the severity of agency problems by unbundling issue dimensions. For example, Matsusaka $(1995,2004)$ shows that states with a direct citizen initiative (allowing voters to reduce the power of agenda control exercised by legislators in noninitiative states) have lower levels of spending than do states without this institution. Gerber (1999) also finds that states with the initiative

\footnotetext{
${ }^{7}$ Cabined by its own terms, the literature on the law of $1 / n$ does not apply to all elected officials but merely to a subset of elected officials. Adding districts to a legislature should exacerbate the common-pool problem underlying the law of $1 / n$, but adding other nonlegislative elected offices should not. On the other hand, adding specialized elected offices unbundles policy authority, whereas adding seats in the legislature does not. We suggest that two distinct forces are at work for these two different types of elected offices. It is therefore critical in empirical analysis to distinguish legislative-body elected officials from non-legislative-body elected officials.

${ }^{8}$ Knight (2006) provides a useful review and synthesis of the literature on common-pool problems in legislatures.
} 
produce social policies that more closely reflect voter preferences. On the other hand, Farnham (1990) finds only modest effects of recalls, initiatives, and referenda on local public expenditures, and Besley and Case (2003) find that inferences about the initiative's effect on fiscal outcomes are highly sensitive to how the model's standard errors are estimated.

However, other theoretical approaches predict no effects of political institutions on fiscal outcomes. Compare the Tiebout (1956) model and its progeny (see generally Sprunger and Wilson 1998; Taylor 1995; Sonstelie and Portney 1978; Rose-Ackerman 1983; Rauscher 1998; Perroni and Scharf 2001). If citizens are mobile, jurisdictions that overextract from their tax base will suffer an exodus of residents and capital. If local governments compete with each other for an increased tax base, then the right bundle of public goods, taxes, and spending should be provided to each group. ${ }^{9}$ The literature on local government competition is expansive, and we wish to make only a gesture in its direction. ${ }^{10}$ However, if it is correct, then institutional variation, such as the number of elected officials or the structure of different governmental units, should be largely irrelevant for determining fiscal outcomes. Voting with one's feet makes voting at the ballot box superfluous, implying that neither the number of officials nor the structure of local government should be systematically associated with government taxation, spending, or borrowing in a perfectly competitive local government "market." "11

\section{Institutional Background}

Because virtually nothing has been written on the local elected offices that are the subject of this paper, we begin by offering an overview of the institutional environment we seek to explore. ${ }^{12}$ Table 1 contains some basic descriptive statistics about the number and distribution of elected officials. In 1992, there were over 500,000 elected officials in the United States in federal, state, and local government. The federal elected officials are largely familiar: senators, representatives, the president, and the vice president.

State government elected officials are a substantially larger class, consisting of more than 18,000 elected officials. Across states, there is significant variation with respect to how many officials are elected. For example, Delaware has only 80 elected state officials, whereas Pennsylvania has 1,200. Forty percent of all state elected officials are members of state legislatures. The remainder consists of other elected officials (53 percent), including executive, administrative, and judicial functions; elected members of state boards (7 percent), including a

\footnotetext{
${ }^{9}$ But see, for example, Epple and Zelenitz (1981) for an argument that Tiebout competition alone is insufficient to constrain government excesses.

${ }^{10}$ Wilson (1999) provides an excellent review of the literature on tax competition.

${ }^{11}$ Unless altering the number of elected officials is systematically the method by which local jurisdictions produce policy in order to compete for citizens.

${ }^{12}$ The discussion is drawn from the 1992 Census of Governments (COG; U.S. Census Bureau 1995), the last to collect detailed data on locally elected officials.
} 
Table 1

Elected Officials and Governments in the United States, 1992

\begin{tabular}{|c|c|c|c|c|c|}
\hline & Total & $\begin{array}{l}\text { Members of } \\
\text { Governing } \\
\text { Boards }\end{array}$ & $\begin{array}{c}\text { Other Elected } \\
\text { Boards }\end{array}$ & $\begin{array}{c}\text { Other Elected } \\
\text { Officials }\end{array}$ & $\begin{array}{l}\text { Number of } \\
\text { Governments }\end{array}$ \\
\hline Federal government & 542 & 540 & & 2 & 1 \\
\hline State governments & 18,828 & 7,461 & 1,331 & 10,036 & 50 \\
\hline $\begin{array}{l}\text { All local governments } \\
\text { General purpose: }\end{array}$ & 493,830 & 342,812 & 40,922 & 110,096 & 85,955 \\
\hline $\begin{array}{l}\text { County } \\
\text { Subcounty: }\end{array}$ & 58,818 & 17,274 & 10,835 & 30,709 & 3,043 \\
\hline $\begin{array}{l}\text { Municipal } \\
\text { Town or township }\end{array}$ & $\begin{array}{l}135,531 \\
126,958\end{array}$ & $\begin{array}{r}107,542 \\
51,770\end{array}$ & $\begin{array}{r}4,157 \\
25,930\end{array}$ & $\begin{array}{l}23,832 \\
49,258\end{array}$ & $\begin{array}{l}19,279 \\
16,656\end{array}$ \\
\hline $\begin{array}{l}\text { Special purpose: } \\
\text { School districts } \\
\text { Special districts }\end{array}$ & $\begin{array}{l}88,434 \\
84,089\end{array}$ & $\begin{array}{l}83,596 \\
82,630\end{array}$ & $\begin{array}{l}\cdots \\
\cdots\end{array}$ & $\begin{array}{l}4,838 \\
1,459\end{array}$ & $\begin{array}{l}14,422 \\
31,555\end{array}$ \\
\hline Total & 513,200 & 350,813 & 42,253 & 120,134 & 86,006 \\
\hline
\end{tabular}

Source. U.S. Census Bureau (1995).

handful of school board members in state-operated school systems (Alaska, Hawaii, Maine, and New Jersey); and soil conservation district boards in Arizona, Delaware, Louisiana, Missouri, and Washington.

The vast majority of elected officials serve in local governments. A staggering 343,000 elected officials are found on the governing boards of counties, municipalities, townships, special districts, and school districts. These governing bodies, such as city councils and school boards, represent the legislative branch of local government. For the purposes of our analysis, we are especially interested in the other 120,000 elected officials who serve in specialized offices of the local executive and judicial branches. To get a sense of the non-governing-body elected officials category, consider Table 2, which lists the numbers of various nongoverning-body elected positions by the different types of local government. For example, there are 324 county executives in the United States and 11,499 mayors of cities and towns. ${ }^{13}$ Certain officials are associated exclusively or almost exclusively with certain levels of government. County executives are of this sort, as are coroners and sheriffs, who are always county officials. There are 2,930 elected county sheriffs in the United States and 1,466 elected coroners. Road or highway commissioners are never county elected offices, but surveyors always are. $^{14}$

\footnotetext{
${ }^{13}$ For a useful summary of the structures of municipal governments, see DeSantis and Renner (2002).

${ }^{14}$ Note that Table 2 is a summary only of elected offices. It says nothing about the number or distribution of appointed offices with the same functions. For certain offices that all governments at a given level must have, it is possible to infer the number of appointed officials. For example, if all counties had coroners, we could calculate the number of appointed coroners by simple subtraction. As a general matter, this is not possible because not all counties, municipalities, or towns have identical slates of offices. However, even if precise figures cannot be obtained, the final column in Table 2 is a rough indicator of the prevalence of electing a given office. For example, only 317 counties elect county executives, whereas 1,177 elect a probate judge.
} 
Table 2

Elected Officials Not Serving on Governing Boards

\begin{tabular}{|c|c|c|c|c|c|}
\hline Office & County & Municipal & Township & Total & $\begin{array}{c}\text { Counties Where } \\
\text { Present }\end{array}$ \\
\hline County executive & 324 & . . & $\ldots$ & 324 & 317 \\
\hline Mayor & . . & 11,380 & 119 & 11,499 & 2,699 \\
\hline Assessor & 1,703 & 636 & 4,907 & 7,246 & 1,997 \\
\hline Attorney & 1,842 & 425 & 67 & 2,334 & 2,018 \\
\hline Auditor & 815 & 1,367 & 4,998 & 7,180 & 853 \\
\hline County clerk & 1,648 & . . & 7 & 1,655 & 1,649 \\
\hline Clerk & $\ldots$ & 3,735 & 12,046 & 15,781 & 1,334 \\
\hline Clerk of the court & 1,812 & 138 & 35 & 1,985 & 1,807 \\
\hline Constable & 3,100 & 176 & 2,830 & 6,106 & 904 \\
\hline Justice of the peace & 2,862 & 482 & 3,161 & 6,505 & 826 \\
\hline County or probate judge & 1,901 & . . & $\ldots$ & 1,901 & 1,177 \\
\hline Municipal judge & . . & 1,360 & 201 & 1,561 & 569 \\
\hline Coroner & 1,466 & . . & . . & 1,466 & 1,386 \\
\hline Sheriff & 2,930 & . . & . . & 2,930 & 2,930 \\
\hline Police chief & . . & 649 & 52 & 701 & 358 \\
\hline Recorder & 1,040 & 351 & 29 & 1,420 & 1,181 \\
\hline Collector & 295 & 4 & 55 & 354 & 326 \\
\hline Treasurer & 2,126 & 2,221 & 8,054 & 12,401 & 2,289 \\
\hline Road or highway commissioner & . . & 120 & 2,423 & 2,543 & 271 \\
\hline Superintendent of schools & 460 & $\ldots$ & 1 & 461 & 459 \\
\hline Surveyor & 562 & . . & $\ldots$ & 562 & 562 \\
\hline Other & 5,716 & 470 & 10,184 & 16,370 & 1,691 \\
\hline
\end{tabular}

Source. U.S. Census Bureau (1995).

The tremendous variation in the number of elected offices from place to place is indicated in Table 3. We begin by creating county-area summaries of the total number of elected offices (excluding governing boards) in all governments. Cook County, Illinois, with a sum total of 370 elected offices in all of its local governments, leads the nation. We then compute our two primary measures of electoral density: the number of elected offices per capita and per general purpose government. The average county area has 1.7 elected offices per 1,000 capita and 4.4 elected offices per government. At the low end, there are six counties where no local government has a non-governing-body office, and these counties register a zero for both measures of electoral density. At the high end, Slope, North Dakota, has 75 elected offices per 1,000 capita, which means that nearly 10 percent of the population serves in a local office.

We are certainly not the first either to observe that variation exists in the structure and size of government or to analyze local government data. Prior studies have emphasized government reform efforts-for example, use of appointed chief executives - as determinants of spending (see Jung [2006] for an overview). ${ }^{15}$ However, although Baqir (2002) and Langbein, Crewson, and

\footnotetext{
${ }^{15}$ A common approach is to ask whether cities that reformed their government structures spend more or less than cities that have not. Some studies conclude that municipal governments of the council-manager form spend less than mayor-council municipalities (Booms 1966; Lineberry and
} 
Table 3

Aggregate County-Area Elected Offices

\begin{tabular}{|c|c|c|c|c|c|c|c|c|}
\hline & \multirow[b]{2}{*}{ Average } & \multirow[b]{2}{*}{ Min } & \multirow{2}{*}{$\begin{array}{c}\text { 25th } \\
\text { Percentile }\end{array}$} & \multirow[b]{2}{*}{ Median } & \multirow{2}{*}{$\begin{array}{c}75 \text { th } \\
\text { Percentile }\end{array}$} & \multirow[b]{2}{*}{ Max } & \multicolumn{2}{|r|}{ County } \\
\hline & & & & & & & $\operatorname{Min}^{\mathrm{a}}$ & Max \\
\hline Total & 26.3 & 0 & 9 & 13 & 33 & 370 & Maui & Cook, Ill. \\
\hline Per 1,000 capita & 1.7 & 0 & .3 & .7 & 1.6 & 74.7 & Maui & Slope, N. Dak. \\
\hline Per government & 4.4 & 0 & 2 & 3 & 5.4 & 90 & Maui & Rutland, Vt. \\
\hline
\end{tabular}

Source. U.S. Census Bureau (1995).

${ }^{a}$ Not a unique minimum. Six counties have no non-governing-body elected officials.

Brasher (1996) find a positive relationship between the number of seats on a city council and the level of expenditures, no one, so far as we are aware, has examined the broader question of the relationship between the number of local elected offices and local government fiscal behavior.

Explaining the genesis and evolution of electoral structure is an important and independent line of inquiry we are pursuing. However, this paper's more modest goal is to analyze the effects of certain types of government structure on policy outcomes. Other ongoing research seeks to analyze why different political jurisdictions structure authority in different ways along this dimension, a subject that has not been previously studied.

\section{Data and Methods}

Because the functional responsibilities of different types of local governments vary across states, we use county aggregates as the unit of analysis. ${ }^{16}$ In some counties, a given service will be provided by a special purpose government; in other counties, the same service will be provided by a general purpose government. However, at the level of county aggregates, in general, a similar bundle of services is provided.

We begin by summing the number of elected offices in all governments within a county. ${ }^{17}$ The number of elected offices is then normalized by the number of governments and by county population to produce two explanatory variables of interest: elected offices per capita and elected offices per government. The numerator, elected offices, is computed by summing the number of total elected offices in the county, excluding officials on governing bodies such as city or county councils. In other words, this variable captures all of the offices listed in

Fowler 1967; Clark 1968; Stumm and Corrigan 1998). Other studies conclude that reformed municipalities spend more (Sherbenou 1961; Nunn 1996; Cole 1971; French 2004). Others find a null effect (Lyons and Morgan 1977; Dye and Garcia 1978; Morgan and Pelissero 1980; Deno and Mehay 1987; Hayes and Chang 1990; Morgan and Watson 1995).

${ }^{16}$ In states that do not officially have county governments, we use the county area, as designated by the Census of Governments.

${ }^{17}$ The number of elected offices is sometimes different than the number of elected officials. The main difference is that some elected offices are occupied by multiple officials. The offices of judge and constable are common examples. 
Table 2. Each office is counted only once, regardless of the number officeholders. We then divide the number of elected offices by the total number of general purpose governments within the county to calculate the per-government measure. The variable for elected offices per government is a rough measure of the degree of unbundling within a county ${ }^{18}$ The more functional elected offices within a county, the greater the degree of unbundling. Similarly, the greater the number of offices, the greater the total costs of monitoring. Both measures indicate what we call the electoral density of a county, and both capture the unbundling and monitoring costs intuition.

By disaggregating the data on elected officials into legislative-body and nonlegislative-body officials, we are able to distinguish two potentially conflicting effects that could easily confound empirical estimates. The average council size for general purpose governments in a county controls for the effect of legislativebody elected officials. If the literature on the law of $1 / n$ is correct, the average city council size should be positively associated with spending.

The main dependent variable is general own-source revenue per capita. The numerator is the sum of own-source revenue across all governments in a county, excluding intergovernmental transfers, and the denominator is county population. Own-source revenue accounts for 58 percent of all local government general revenue. ${ }^{19}$ The substantive conclusions hold with alternative dependent variables, including direct general expenditures per capita and expenditures on specific budget line items.

Electoral institutions are obviously not the only or even the primary determinants of local fiscal patterns. We use a set of control variables with a strong foundation in the prior literature. The first control is income per capita. According to Wagner's Law, the demand for government services should increase with income (Musgrave and Peacock 1958). Second, population characteristics may reflect tastes for public goods (Cutler, Elmendorf, and Zeckhauser 1993). The proportion of families with children controls for demand for education, as does the fraction of the population older than 65 because older populations often prefer lower spending on education (Poterba 1997). Additional costs may also be associated with serving an elderly population. Third, to control for the ideological orientation of the county, we use the Republican vote share in the 1992 presidential election. We also control for educational attainment, as measured by the percentage of adults with a college degree.

Alesina, Baqir, and Easterly (1999) argue that population heterogeneity leads to increased pressure for group-specific spending programs but fewer nonexcludable public goods. Although their theoretical model is ambiguous as to the

\footnotetext{
${ }^{18}$ We have experimented with other measures as well. Most alternatives have a simple correlation coefficient in excess of .95 . No alternative that we have tried produces different conclusions.

${ }^{19}$ In principle, the aggregate tax rate is an ideal dependent variable. However, as a result of variation in assessment practices across jurisdictions and complexity of tax codes, calculating the effective tax rate in a county is prohibitively difficult. We discuss results using alternative dependent variables in Section 6.3.
} 
net effects, their empirical results show a positive association between ethnic heterogeneity and total expenditures and taxes. Following Alesina, Baqir, and Easterly (1999), we measure ethnic fragmentation as the probability that two randomly drawn people from a county belong to different ethnic groups. ${ }^{20}$ Income heterogeneity is measured as the ratio of the mean household income to the median household income in a county. Along these lines, Meltzer and Richard (1981, 1983) argue that increasing inequality causes greater demand for redistribution and, hence, higher taxes.

To address economies-of-scale considerations, we control for county population and land area. ${ }^{21}$ In addition, we include a dummy variable indicating whether a county is the central county of a metropolitan statistical area (MSA) and another dummy for suburban counties within MSAs. ${ }^{22}$ The omitted category is nonmetropolitan counties. These central and suburban county indicators capture possible sorting by taste as well as potential economies of scale in MSAs. Finally, states also vary in their assignment of fiscal responsibilities to local governments and in unobservable historical, cultural, and institutional characteristics that may influence both electoral density and fiscal outcomes. For this reason, we include state fixed effects in all of the models reported below. ${ }^{23}$

Our main data sources are the Census of Governments (COG; U.S. Census Bureau 1990, 1995), the 1990 Census of Population and Housing (CPH; U.S. Census Bureau 1992), and the 1994 County and City Databook (CCD; U.S. Census Bureau 1994). The data source for each variable is specified in Table 4. Our selection criteria ${ }^{24}$ produce an analysis sample of 2,965 counties. $^{25}$ Table 3

\footnotetext{
${ }^{20}$ Specifically, ethnic fragmentation is computed as follows: Ethnic $=1-\sum_{i}\left(\text { Race }_{i}\right)^{2}$, where Race ${ }_{i}$ denotes the share of population identified as being of race $i$ and $i=\{$ White, Black, Hispanic, Asian and Pacific Islander, American Indian\}. Note that Hispanic is identified as an origin rather than a race in the census, so we count only non-Hispanic Whites, Blacks, Asian and Pacific Islanders, and American Indians for those categories. This same measure has been used in numerous prior studies; see the references in Alesina, Baqir, and Easterly (1999). For a theoretical interpretation of this index, see Vigdor (2002).

${ }^{21}$ One concern with this setup is that county population appears as both the denominator of the dependent variable and on the right-hand side of the equation. Therefore, we also ran the analysis excluding county population. The coefficients changed, of course, but the substantive conclusions did not.

${ }^{22}$ In New England, the Census Bureau specifies central cities and towns rather than central counties of metropolitan statistical areas (MSAs). In these states, we define any county containing a central city or town as a central county.

${ }^{23}$ The state fixed effects coefficients are not reported in the tables but are available from the authors on request.

${ }^{24}$ We exclude Virginia (134 observations), Hawaii (four observations), and Alaska (27 observations) from the analysis. Virginia is the only state whose municipalities are incorporated as independent cities that are not part of any county. Hawaii has the only entirely state-run public school system. Alaska uniquely relies on boroughs rather than counties, and boroughs do not cover the entire land area of the state. Anomalously, the COG reports one record for New York City but no records for its five component counties. Not being able to produce a county aggregate record, we drop the New York City observation. Alesina, Baqir, and Easterly (1999) also discuss this issue and make the same decision. In addition, we exclude Shannon County, South Dakota, population 10,490, which is the only county that has no elected officials outside the county governing body.

${ }^{25}$ There are some minor discrepancies in how counties are counted in the COG versus the Census
} 


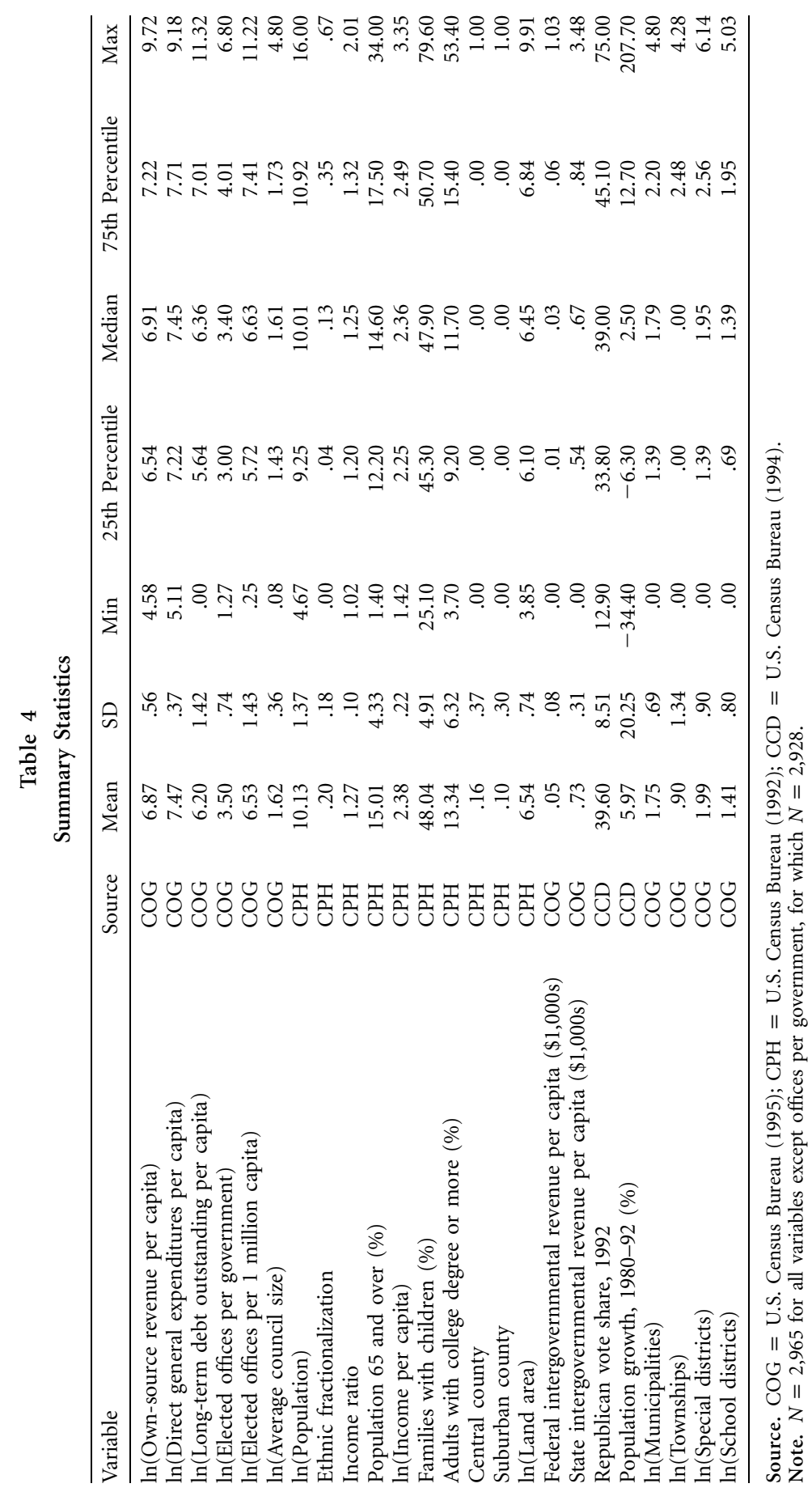


presents summary statistics for various measures of electoral density for all counties, whereas Table 4 presents summary statistics for all the variables based on the 2,965 counties selected for the analysis.

\section{Findings}

Our main theoretical contribution is to offer a significant extension and application of the unbundling intuition for electoral institutions (Besley and Coate 2001, 2003). The inclusion of monitoring costs in the unbundling framework produces different theoretical implications and empirical predictions. Instead of suggesting a negative and largely linear effect of unbundling on slack in politics, a diminishing — and potentially negative — return to unbundling may result. Adding nonlegislative elected officials in a jurisdiction should reduce slack by unbundling but should also increase monitoring costs. If our theory is correct, spending should decrease initially as unbundling produces greater control over elected officials and subsequently increase as the marginal costs swamp any unbundling gain.

To test this proposition, we estimate polynomial regression models of revenue raising in local government. Because of the restrictive functional form assumptions inherent in the polynomial regression context, we also use a semiparametric generalized additive model (GAM) in which we estimate the effect of electoral density with thin-plate regression splines and allow all of the other covariates to enter the model linearly. ${ }^{26}$ Both methods produce similar results. The relationship appears to be $U$ shaped, and the turning point is at an interior location in the actual data.

An obvious concern with any study of the fiscal effects of political institutions is endogeneity - namely, the possibility of simultaneous causation between institutional form and fiscal policy (see Persson and Tabellini 2003). In other words, measures of electoral density may be correlated with the errors in an ordinary least squares regression, leading to biased estimates. To a large degree, concerns about reverse causation in this case should be allayed by the fact that electoral institutions are enshrined in longstanding provisions of state constitutions and city charters. For example, a set of state dummy variables explains more than half of the variation in electoral density across counties. ${ }^{27}$ Moreover, the correlation between county-area elected offices per government in 1992 and 1987 is .97. Thus, it is unlikely that electoral institutions change quickly in response

of Population and Housing, primarily in Virginia and Alaska, which explain why the former tallies 3,135 counties and the latter 3,034. For models that measure electoral density as offices per government, we exclude an additional 37 counties that have no general purpose governments, leaving an analysis sample of 2,928 .

${ }^{26}$ The seminal reference on generalized additive models is Hastie and Tibshirani (1990). Beck and Jackman (1998) provide an accessible introduction. Our implementation follows Wood (2006) and the associated $\mathrm{R}$ package, mgcv.

${ }^{27}$ A regression of county aggregate elected offices per government on a set of state dummy variables yields an adjusted $R^{2}$-value of .54 , with 2,928 observations in our analysis sample. 
to local spending preferences. In this sense, we believe it is safe to consider electoral institutions as predetermined, at least in the short run.

\subsection{Elected Offices and Revenue}

To estimate the effect of electoral institutions on fiscal outcomes, we regress a log-transformed measure of each county's own-source revenues per capitaa standard measure used in the public finance literature - on measures of elected offices per unit of government and per capita and their square. This is a straightforward polynomial regression model. The main results indicate that adding elected offices decreases taxing at the low end of the distribution but increases taxing after a certain point in the data. Specifically, the relationship between specialized elected offices and taxing appears to be roughly $U$ shaped. This is true regardless of how electoral institutions are measured, and the result is robust to a range of alternative specifications.

Columns 1 and 3 of Table 5 present coefficients for a simple polynomial equation without controls. Columns 2 and 4 present the coefficient estimates with the full controls included. The substantive conclusions are not sensitive to the inclusion of controls. We therefore focus our discussion on the full equations. Because the estimated model is a log-log regression, the coefficients represent elasticities, or the percentage change in the dependent variable of interest produced by a percentage change in the independent variable of interest. Note that the coefficient on elected offices is negative and the coefficient on the squared variable is positive and statistically significant in all the models. ${ }^{28}$

First, consider the model using elected offices per government (model 2). Both the linear and squared versions of the variable are statistically significant $(p<$ $.10)$. The main variable has a negative effect, whereas the squared term has a positive effect. The 1st percentile value of the main explanatory variable (log of elected offices per 10 general purpose governments) is 1.8; the 99th percentile value is 5.5 in the data. The observed turning point is at the 40th percentile of the data, which corresponds to approximately 2.6 offices per government, a threshold for which about 1,750 counties have a higher value-that is, 40 percent of the counties in the sample have fewer elected offices per government than the turning point. Adding elected offices to these counties would reduce, rather than increase, overall revenue raising. For 60 percent of the counties, however, adding elected offices would actually increase spending. The estimates from the

\footnotetext{
${ }^{28}$ Including a squared version of another independent variable in the regression generates significant collinearity. The simple correlations are approximately .97 . This does not produce biased coefficient estimates; however, it does affect the standard errors of the coefficients. To address this issue, in models not shown here, we mean deviated the explanatory variable of interest before squaring. This linear transformation produces identical coefficients but reduces collinearity significantly. The relevant coefficient standard errors fall substantially.
} 
Table 5

Polynomial Regression Models of Own-Source Revenue

\begin{tabular}{|c|c|c|c|c|}
\hline & (1) & (2) & (3) & (4) \\
\hline $\ln ($ Elected offices per government) & $\begin{array}{l}-.286^{* \star} \\
(.095)\end{array}$ & $\begin{aligned}-.149^{+} \\
(.083)\end{aligned}$ & & \\
\hline $\ln (\text { Elected offices per government })^{2}$ & $\begin{array}{l}.033^{*} \\
(.013)\end{array}$ & $\begin{array}{l}.023^{*} \\
(.011)\end{array}$ & & \\
\hline $\ln$ (Elected offices per 1 million capita) & & & $\begin{array}{l}-.445^{* *} \\
(.041)\end{array}$ & $\begin{array}{l}-.198^{* *} \\
(.051)\end{array}$ \\
\hline $\ln$ (Elected offices per 1 million capita $)^{2}$ & & & $\begin{array}{l}.033^{* *} \\
(.003)\end{array}$ & $\begin{array}{l}.018^{* *} \\
(.003)\end{array}$ \\
\hline $\ln$ (Average council size) & & $\begin{array}{l}.096^{*} \\
(.045)\end{array}$ & & $\begin{array}{l}.101^{*} \\
(.043)\end{array}$ \\
\hline $\ln$ (Income per capita) & & $\begin{array}{l}1.336^{* *} \\
(.081)\end{array}$ & & $\begin{array}{l}1.386^{* *} \\
(.079)\end{array}$ \\
\hline $\ln ($ Population) & & $\begin{array}{c}-.349^{* *} \\
(.070)\end{array}$ & & $\begin{array}{r}-.220^{*} \\
(.097)\end{array}$ \\
\hline $\ln (\text { Population })^{2}$ & & $\begin{array}{l}.015^{* *} \\
(.003)\end{array}$ & & $\begin{array}{l}.009^{+} \\
(.004)\end{array}$ \\
\hline Ethnic fractionalization & & $\begin{array}{l}.228^{* *} \\
(.080)^{* *}\end{array}$ & & $\begin{array}{l}.219^{* *} \\
(.079)\end{array}$ \\
\hline Income ratio & & $\begin{array}{c}-.379 \\
(.131)\end{array}$ & & $\begin{array}{l}-.329^{* *} \\
(.127)\end{array}$ \\
\hline Population 65 and older (\%) & & $\begin{array}{l}.026^{* *} \\
(.005)\end{array}$ & & $\begin{array}{l}.020^{* *} \\
(.005)\end{array}$ \\
\hline Families with children (\%) & & $\begin{array}{l}.019^{* *} \\
(.004)\end{array}$ & & $\begin{array}{l}.018^{* *} \\
(.004)\end{array}$ \\
\hline Adults with college degree or more $(\%)$ & & $\begin{array}{l}.008^{* *} \\
(.002)\end{array}$ & & $\begin{array}{l}.006^{* *} \\
(.002)\end{array}$ \\
\hline Central county & & $\begin{array}{r}-.071^{*} \\
(.034)\end{array}$ & & $\begin{array}{r}-.071^{\star} \\
(.034)\end{array}$ \\
\hline Suburban county & & $\begin{array}{l}-.137^{* *} \\
(.026)\end{array}$ & & $\begin{array}{c}-.141^{* *} \\
(.026)\end{array}$ \\
\hline $\ln ($ Land area $)$ & & $\begin{array}{l}.094^{* *} \\
.018)\end{array}$ & & $\begin{array}{l}.106^{* *} \\
.018)\end{array}$ \\
\hline $\begin{array}{l}\text { Federal intergovernmental revenue per } \\
(\$ 1,000 \mathrm{~s})\end{array}$ & & $\begin{array}{l}.418^{* *} \\
(.119)\end{array}$ & & $\begin{array}{l}.421^{* *} \\
(.115)\end{array}$ \\
\hline $\begin{array}{l}\text { State intergovernmental revenue per cap } \\
\quad(\$ 1,000 \mathrm{~s})\end{array}$ & & $\begin{array}{l}.128^{* *} \\
(.047)\end{array}$ & & $\begin{array}{l}.094^{*} \\
(.046)\end{array}$ \\
\hline Republican vote share, 1992 & & $\begin{array}{c}-.001 \\
(.001)\end{array}$ & & $\begin{array}{c}-.001 \\
(.001)\end{array}$ \\
\hline Population growth $1980-92$ & & $\begin{array}{c}-.003^{* *} \\
(.001)\end{array}$ & & $\begin{array}{c}-.003^{* *} \\
(.001)\end{array}$ \\
\hline $\ln$ (Municipalities) & & $\begin{array}{c}-.042^{+\star} \\
(.025)\end{array}$ & & $\begin{array}{c}-.062^{* *} \\
(.022)\end{array}$ \\
\hline $\ln$ (Townships) & & $\begin{aligned}-.010 \\
(.018)\end{aligned}$ & & $\begin{array}{r}-.038^{+} \\
(.022)\end{array}$ \\
\hline $\ln ($ Special districts) & & $\begin{array}{l}.068^{* *} \\
(.016)\end{array}$ & & $\begin{array}{l}.076^{* *} \\
(.016)\end{array}$ \\
\hline $\ln ($ School districts $)$ & & $\begin{array}{c}-.056^{* *} \\
(.021)\end{array}$ & & $\begin{array}{c}-.033 \\
(.022)\end{array}$ \\
\hline $\begin{array}{l}\text { Adjusted } \mathrm{R}^{2} \text {-value } \\
N\end{array}$ & $2,928^{.01}$ & $2,928^{.25}$ & $2,965^{.05}$ & $2,965^{.27}$ \\
\hline Counties above turning point & 401 & 1,753 & 1,322 & 2,368 \\
\hline
\end{tabular}

Note. Robust standard errors are in parentheses. All models include state fixed effects (not reported). Electoral density is measured as $\ln$ (elected offices per 10 general purpose governments) and as $\ln$ (elected offices per 1 million capita). The dependent variable is $\ln ($ own-source revenue per capita).

$$
\begin{aligned}
& { }^{+} p<.10 . \\
& { }^{*} p<.05 . \\
& { }^{*} p<.01 .
\end{aligned}
$$


Table 6

Predicted Own-Source Revenues at Different Values of Electoral Density: Elected Offices per Government

\begin{tabular}{lccccr}
\hline Percentile & $\begin{array}{c}\text { In(Elected Offices per } \\
\text { 10 Governments) }\end{array}$ & $\begin{array}{c}\text { Elected Offices } \\
\text { per Government }\end{array}$ & $\begin{array}{c}\text { Predicted } \\
\text { Revenue } \\
(\$)\end{array}$ & $\begin{array}{c}1 \text { st } \\
\text { Difference }\end{array}$ & $\begin{array}{c}2 \mathrm{~d} \\
\text { Difference }\end{array}$ \\
\hline 1 & 1.83 & .63 & 878.65 & & \\
5 & 2.42 & 1.12 & 852.26 & -26.39 & \\
10 & 2.64 & 1.40 & 846.04 & -6.21 & -32.61 \\
25 & 3.00 & 2.00 & 839.90 & -6.14 & -12.36 \\
50 & 3.40 & 3.00 & 838.85 & -1.05 & -7.20 \\
75 & 4.01 & 5.50 & 849.03 & 10.18 & 9.13 \\
90 & 4.50 & 9.00 & 868.01 & 18.98 & 29.17 \\
95 & 4.70 & 11.00 & 878.64 & 10.63 & 29.61 \\
99 & 5.44 & 23.00 & 933.43 & 54.79 & 65.42 \\
\hline
\end{tabular}

Note. Percentiles are the empirical distributions of electoral density. The final two columns present margina shifts in revenue, equivalently, the difference between the given and immediately prior listed percentile (or two prior listed percentiles) of electoral density. For computing the predicted values, all covariates are set at means except dummy variables, which are set to their mode.

per capita measures (model 4) support similar conclusions. ${ }^{29}$ The 1 st percentile of log of elected offices per million capita is 2.75 ; the 99th percentile value is 9.7. The estimated turning point is 5.46 , at approximately the 20th percentile. In untransformed terms, the turning point is .24 offices per 1,000 capita (corresponding to the same 20th percentile of the data). In sum, the polynomial regression models of own-source revenues support the hypothesis of a $\mathrm{U}$-shaped relationship between specialized elected officials and taxing.

To get a better sense of the magnitude of these effects, Tables 6 and 7 present the difference in predicted mean revenues, setting continuous covariates to their means and dummy variables to their modes and allowing the measures of electoral density to vary. ${ }^{30}$ To illustrate, the value corresponding to the 5 th percentile of the number of elected offices per government is 2.42 , which produces a predicted level of per capita revenues of approximately $\$ 852$. The value of the variable for elected offices per 10 governments at the 10th percentile is 2.64 , which produces a predicted mean level of per capita revenues of $\$ 846$. Moving from the 5th percentile to the 10th percentile therefore produces a net decrease in own-source revenues of approximately $\$ 6$. Again, the estimated turning point

${ }^{29}$ The variables for both elected offices per capita and elected offices per government contain values less than one. When these negative values are squared, the ordering of the underlying data is not maintained because both negative and positive numbers are treated identically after transformation. To preserve the original ordering, we simply express the first variable as elected offices per 1 million capita and the second as offices per 10 governments. The addition of a constant produces identical coefficient estimates on the untransformed term but avoids changing the ordering of the original data.

${ }^{30}$ The values of the distribution points are summaries of the log of elected offices per 10 general purpose governments (Table 6) and the log of elected offices per 1 million people (Table 7). The first differences represent changes in per capita revenues raised shifting from row $i$ in the tables to row $i+1$. 
Table 7

Predicted Own-Source Revenues at Different Values of Electoral Density: Elected Offices per Capita

\begin{tabular}{|c|c|c|c|c|c|}
\hline Percentile & $\begin{array}{l}\ln (\text { Elected Offices } \\
\text { per } 1 \text { Million } \\
\text { Capita })\end{array}$ & $\begin{array}{c}\text { Elected Offices } \\
\text { per } 1,000 \\
\text { Capita }\end{array}$ & $\begin{array}{l}\text { Predicted } \\
\text { Revenue } \\
\quad(\$)\end{array}$ & $\begin{array}{c}\text { 1st } \\
\text { Difference }\end{array}$ & $\begin{array}{c}2 \mathrm{~d} \\
\text { Difference }\end{array}$ \\
\hline 1 & 2.76 & .02 & 917.56 & & \\
\hline 5 & 3.94 & .05 & 838.60 & -78.95 & \\
\hline 10 & 4.64 & .10 & 814.26 & -24.35 & -103.30 \\
\hline 25 & 5.72 & .31 & 805.44 & -8.82 & -33.16 \\
\hline 50 & 6.63 & .76 & 824.73 & 19.30 & 10.48 \\
\hline 75 & 7.41 & 1.66 & 861.98 & 37.24 & 56.54 \\
\hline 90 & 8.27 & 3.92 & 928.29 & 66.31 & 103.56 \\
\hline 95 & 8.82 & 6.79 & 987.02 & 58.73 & 125.04 \\
\hline 99 & 9.77 & 17.47 & 1125.47 & 138.45 & 197.18 \\
\hline
\end{tabular}

Note. Percentiles are the empirical distributions of electoral density. The final two columns present marginal shifts in revenue, equivalently, the difference between the given and immediately prior listed percentile (or two prior listed percentiles) of electoral density. For computing the predicted values, all covariates are set at means except dummy variables which are set to their mode.

in the polynomial regression model is at the 40th percentile. At this point in the distribution of elected offices per government, the predicted mean of ownsource revenues is $\$ 838$. Small shifts at or around the 40 th percentile of the data produce virtually no changes in revenues. The results are essentially similar for the per capita measure of elected offices.

The costs of monitoring additional elected offices may, at some point, offset the benefits of issue unbundling, leading to a roughly $U$-shaped relationship with spending, but there is no special reason to expect that this relationship is quadratic per se. To test the sensitivity of our results to functional form assumptions, we estimate the effects of elected offices semiparametrically using a GAM with thin-plate regression splines and allow all of the other covariates to enter the model linearly. The results are summarized in Figure 1, which represents the relationship between the measures of electoral density and revenue raising. ${ }^{31}$ Solid lines represent point estimates; dashed lines represent 95 percent confidence intervals. In each of the graphs, the curve is downward sloping and turns upward at a point well within the data. The $U$ shape is clearly evident in the estimated effects of elected offices per capita. Put simply, the results from the GAM lend further support to the conclusions of the simple polynomial regression model. The relationship between electoral institutions and fiscal policy is not linear; rather, increasing the number of elected officials reduces revenue raising in counties with few elected officials but increases spending in counties with many elected officials. The quadratic fit in the linear models achieves a satisfactory approximation of the underlying relationship.

Returning to Table 5, we see another notable result: as the average size of

${ }^{31}$ The results are similar for both the per capita and per-government measures. We therefore present only the per capita figures herein. 


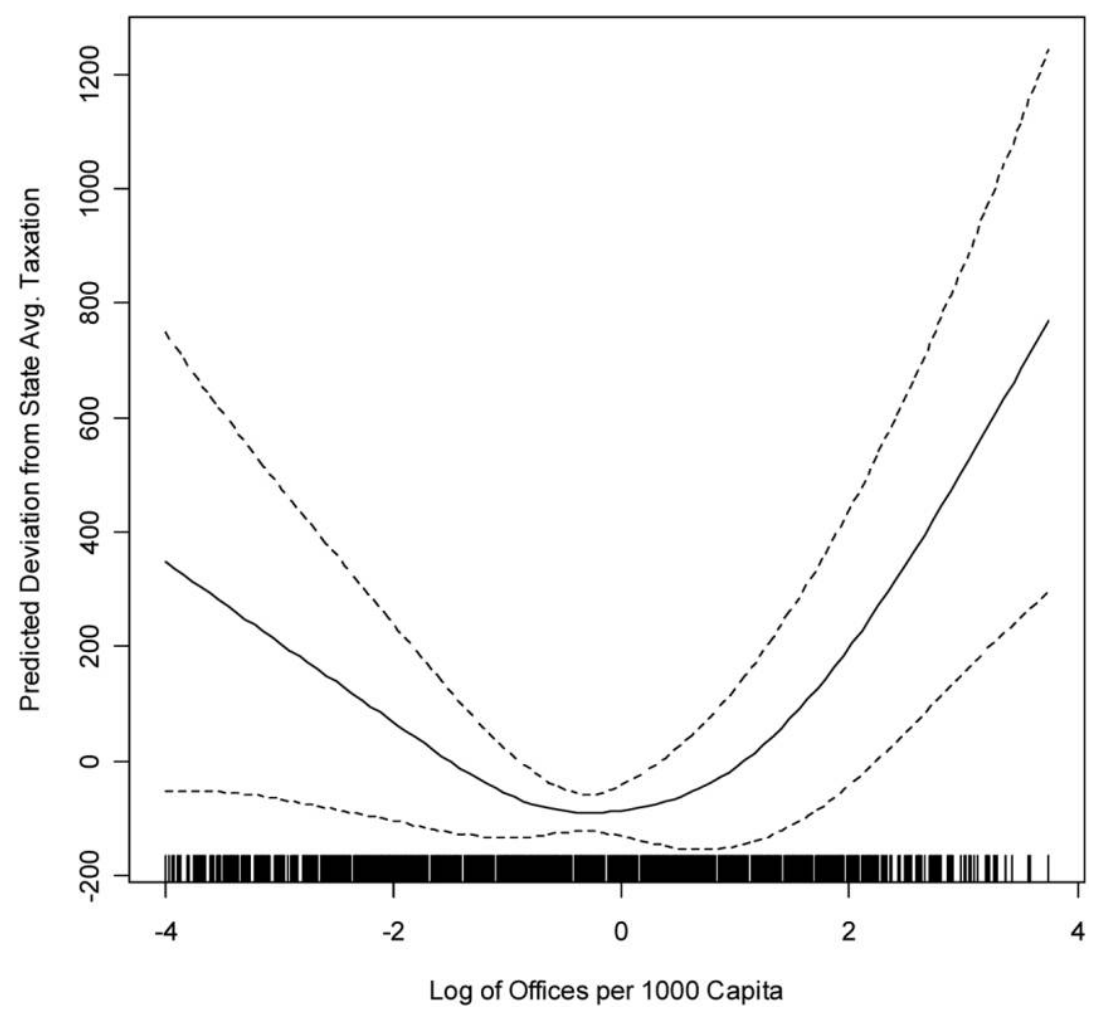

Figure 1. Generalized additive model estimates of own-source revenue

legislative bodies in a county increases, taxation and spending increase as well. In all the models, the coefficient hovers at approximately .10; a 1-percentagepoint increase in the average size of the governing body produces an increase of roughly .1 percentage point in revenue raised from own sources. This result is consistent with prior findings from Baqir (2002), who finds an elasticity of .11 in a comparable model. Putting the results together, we see that increasing the size of legislative bodies increases taxing, but adding other nonlegislative elected officials can reduce or can increase taxing, depending on how many elected officials are already present in the jurisdiction. These findings are consistent with the law of $1 / n$, as well as the theory of unbundling and monitoring costs. The coefficients on the covariates are not of primary interest to our work. However, it is reassuring that the findings are largely consistent with the existing literature. ${ }^{32}$ Moreover, identical conclusions follow when the dependent variable

${ }^{32}$ The other control variables are fairly standard in the literature. However, a few coefficients are noteworthy. First, income is an important determinant of own-source revenue, and the elasticity is greater than one, as predicted by Wagner's law $(b=1.3$ in the equation including elected offices 
is replaced with measures of aggregate expenditures, many line-item expenditures, and the use of debt by governments.

\subsection{First-Differences Analysis}

The results presented thus far are based on cross-sectional county aggregate data for 1992. We have argued that electoral institutions can be considered predetermined in the short run, thus mitigating some of the usual concerns with cross-sectional analysis. Nevertheless, in this section we test the robustness of our results by estimating the main findings in first differences. Differencing the data strips away the effects of any observable or unobservable variables that do not change over time. Thus, this strategy addresses any lingering concerns about omitted variables that may influence both electoral institutions and fiscal outcomes.

Data on elected offices in local governments are available in electronic form from the COG for 1987 and 1992 (U.S. Census Bureau 1990, 1995). We merge these 2 years of data to create a short panel of county aggregate data. Consistent with our argument that electoral institutions do not change quickly, we note that we do not have a great deal of between-year variation in our measures of electoral density. The correlation between elected offices per government in 1987 and 1992 is .97; for elected offices per capita, it is .96. Nevertheless, 370 counties spanning 42 states changed their number of elected offices per government by at least one office between 1987 and 1992, which provides a basis for identification in our first-difference models. In any event, the relatively modest cross-year variation should, if anything, bias the analysis against finding significant effects.

Because most of our demographic variables are from the 1990 census, we are not able to include them in the first-difference models; we do not have independent values for 1992 and 1987. However, the effects of these and other

per government and $b=1.4$ in the equation including elected offices per capita). In addition, the degree of ethnic fractionalization is positive and statistically significant, whereas the ratio of mean to median income, a rough measure of the degree of economic heterogeneity in the jurisdiction, shows a significant negative relationship with own-source revenue. These estimates are consistent with prior work (Alesina, Baqir, and Easterly 1999). Counties with more children proportionally raise slightly more own-source revenues than do counties with fewer children, as do counties with a higher proportion of college graduates. In addition, suburban counties spend significantly less than central or rural counties, which could reflect sorting by preferences or greater interjurisdictional competition (Schneider 1989). We also find a quadratic relationship between county population and own-source revenue, consistent with Baqir (2002). Population growth is negatively associated with own-source revenue, which may suggest that it takes time for spending to catch up with population in rapidly growing areas. The coefficients on federal intergovernmental revenue per capita and state intergovernmental revenue per capita are positive and statistically significant in both models. Counties with governments that receive more intergovernmental revenue per capita also raise more per capita from own-source revenues, consistent with the "flypaper" effect (see, for example, Hines and Thaler, 1995). One concern with these results is that intergovernmental revenue may be jointly determined with own-source revenue. In results not shown, we reestimated all the models in the paper excluding the intergovernmental revenue variables. The results for electoral density did not change notably. Finally, in both sets of equations, partisanship appears to matter relatively little. The proportion of the county that voted for the Republican presidential candidate in 1992 produces virtually no change in the level of own-source revenue per capita. 
variables that do not change significantly over the 5 -year period will be washed out in the first differencing. We do include as predictors a smaller set of variables for which we are able to measure changes between 1987 and 1992. These include average council size, population and its square, and the number of governments of different types in the county. In addition, we include a functional performance index (FPI) that sums nationwide median spending for each service provided in the county. ${ }^{33}$ The FPI should capture changes in spending over time that are associated with changes in functional performance.

Table 8 presents results of the first-differences models ${ }^{34}$ in which we regress changes in own-source revenue between 1987 and 1992 on changes in the independent variables. The results are consistent with our cross-sectional models. In all specifications, there is a statistically significant quadratic relationship between electoral density and own-source revenues. We can, therefore, be reasonably confident that the cross-sectional results presented above are not driven by omitted variable bias.

Interestingly, however, the results for council size change notably in the firstdifferences model. There is a significant negative effect of average council size in both models, which is at odds with the positive coefficient from the crosssectional models. In models not shown, we also find a positive effect of council size when we exclude the other independent variables. The most natural interpretation of these results is that the positive effects of council size in the crosssectional analyses are due to omitted variable bias. Because council size is not our main variable of interest, we do not pursue the issue further here.

\subsection{Robustness}

None of the main substantive conclusions are sensitive to a variety of changes in modeling decisions or estimation methods. First, in the results presented, robust standard errors are used to account for heteroskedasticity. Clustered standard errors, however, were not used because the state fixed effects in all of the models effectively transform the observations to deviations from state means. With only one observation per county, there is little a priori reason to expect

\footnotetext{
${ }^{33}$ The functional performance index (FPI) is defined as follows. For each functional spending category in the COG, we create a binary variable for each county indicating whether the county has positive spending for that function. Next we compute median spending on each function among those counties in which the function is provided. For each county, we then sum nationwide median spending on each function it provides. This summary index indicates the amount a county would spend if it spent the nationwide median amount on each service it provides. Formally, the index is defined as follows: $\mathrm{FPI}_{j}=\sum_{i} \alpha_{i j} \mu_{i}$, where $i$ indexes functional spending categories and $j$ indexes counties; $\alpha_{i j}$ is one if county $j$ provides service $i$ and zero if it does not, and $\mu_{i}$ represents nationwide median spending on service $i$ among all counties that provide the service. Thus, a county's FPI will increase whenever it adds a new service and whenever nationwide median spending on its existing services increases. This is a variation on the method of Clark, Ferguson, and Shapiro (1982).

${ }^{34}$ Because we have only two time periods, fixed effects and first-differences models produce identical results.
} 
Table 8

First-Differences Estimates, 1987-92

\begin{tabular}{|c|c|c|c|c|}
\hline & (1) & (2) & (3) & (4) \\
\hline $\ln$ (Elected offices per government) & $\begin{array}{r}-.256^{\star} \\
(.121)\end{array}$ & $\begin{array}{r}-.206^{\star} \\
(.103)\end{array}$ & & \\
\hline $\ln (\text { Elected offices per government })^{2}$ & $\begin{array}{c}.049^{*} \\
(.020)\end{array}$ & $\begin{array}{l}.039^{*} \\
(.017)\end{array}$ & & \\
\hline $\ln$ (Elected offices per 1 million capita) & & & $\begin{array}{r}-.153^{\star} \\
(.071)\end{array}$ & $\begin{array}{r}-.162^{\star} \\
(.077)\end{array}$ \\
\hline $\ln (\text { Elected offices per } 1 \text { million capita })^{2}$ & & & $\begin{array}{r}.014^{\star} \\
(.006)\end{array}$ & $\begin{array}{l}.017^{\star *} \\
(.007)\end{array}$ \\
\hline $\ln ($ Average council size $)$ & & $\begin{array}{c}-.080^{\star *} \\
(.024)\end{array}$ & & $\begin{array}{c}-.067^{\star *} \\
(.025)\end{array}$ \\
\hline $\ln$ (Population) & & $\begin{array}{l}1.105^{\star \star} \\
(.403)\end{array}$ & & $\begin{array}{l}1.565^{\star \star} \\
(.401)\end{array}$ \\
\hline $\ln (\text { Population })^{2}$ & & $\begin{array}{r}-.042^{\star} \\
(.019)\end{array}$ & & $\begin{array}{c}-.061^{\star *} \\
(.019)\end{array}$ \\
\hline $\ln$ (Functional performance index) & & $\begin{array}{l}1.233^{\star \star} \\
(.090)\end{array}$ & & $\begin{array}{l}1.227^{\star *} \\
(.090)\end{array}$ \\
\hline $\ln$ (Municipalities) & & $\begin{array}{l}.097 \\
(.109)\end{array}$ & & $\begin{array}{c}-.030 \\
(.092)\end{array}$ \\
\hline $\ln$ (Townships) & & $\begin{array}{c}-.031 \\
(.026)\end{array}$ & & $\begin{array}{r}-.055^{+} \\
(.032)\end{array}$ \\
\hline $\ln$ (Special districts) & & $\begin{array}{l}.013 \\
(.015)\end{array}$ & & $\begin{array}{l}.013 \\
(.015)\end{array}$ \\
\hline $\ln$ (School districts) & & $\begin{array}{c}.096^{*} \\
(.047)\end{array}$ & & $\begin{array}{c}.098^{\star} \\
(.046)\end{array}$ \\
\hline Adjusted $\mathrm{R}^{2}$-value & .01 & .14 & .01 & .14 \\
\hline$N$ & 2,931 & 2,931 & 2,968 & 2,967 \\
\hline
\end{tabular}

Note. The dependent variable is $\ln$ (own-source revenue per capita). Robust standard errors are in parentheses. Electoral density is measured as $\ln$ (elected offices per 10 general purpose governments) and as $\ln$ (elected offices per 1 million capita).

${ }^{+} p<.10$.

$* p<.05$.

${ }^{\star *} p<.01$.

within-state correlations in the residuals from the mean-deviated regressions. ${ }^{35}$ Nevertheless, to test the sensitivity of our results to this methodological choice and to account for any possible pattern of within-state correlation in the residuals, each model was estimated using standard errors clustered by state. Although the clustered standard errors are somewhat larger than those reported, the results remain significant at conventional levels in every case. Second, the results are robust to an alternative indicator of the main dependent variable. Ideally, the aggregate local tax rate would be the main dependent variable, but such data are not readily available. In the results presented, own-source revenue per capita is used as a rough proxy for the local tax rate, consistent with the empirical literature on local public finance. As a robustness exercise, however, all the models

\footnotetext{
${ }^{35}$ If we had a panel of data with multiple years for each county, serial correlation would be an obvious concern (Bertrand, Duflo, and Mullainathan 2004), but with only 1 year of data, serial correlation is not at issue here. The same point applies to the first-difference models (Table 8), where we have only one observation (that is, one difference) per county.
} 
were reestimated with 1992 aggregate county income (based on data from the Bureau of Economic Analysis's Regional Economic Information System) as the denominator for the dependent variable. In all cases, the results are substantively unchanged. Finally, several of our control variables, such as state and federal aid and the number of local governments, could conceivably be endogenous. The results, however, are robust to dropping those variables from any of the models reported above.

\section{Discussion}

The theoretical and empirical literature in economics and political science contains divergent predictions about the relationship between electoral institutions and the fiscal behavior of governments. One collection of scholarship predicts that overspending bias will increase with the number of elected officials. Another predicts that increasing the number of elected offices will improve the ability of voters to manage the principal-agent problem of representation. A third predicts that policy outcomes will be largely invariant to the number or nature of electoral institutions.

Against this backdrop, we have sought to make two theoretical contributions. First, we have emphasized that all elected officials are not identical. Adding elected officials serving in districted general purpose legislative bodies may well produce increases in spending and greater slack between voters and politicians. However, when new elected offices generate unbundling, voter control over politicians should increase. The precise form of electoral institutions matters. Second, although we find nascent work on unbundling to be extremely promising, we also suggest that it is incomplete in its current form. Unbundling should help manage agency problems, but it often also produces new monitoring costs. A theory of electoral institutions must account for both.

Our main empirical contribution has been to offer evidence of a U-shaped relationship between elected offices in local government and patterns of government taxing and spending. An important, if secondary, empirical contribution is to demonstrate that the relationship between council size and spending is sensitive to the inclusion of unit-level fixed effects, although more work is clearly warranted to explain why. In any case, we find little evidence that electoral institutions are irrelevant to the fiscal behavior of local government. Our analysis then supports the basic idea that elections matter but adds significant nuance to this claim.

If our theoretical apparatus is correct, it suggests a number of potential future research questions. Perhaps most important, we have treated institutional variation as exogenous for purposes of our analysis, but it is clear that institutional choices-perhaps made long ago-shape the local political and fiscal landscape in important ways. Investigating the sources of these institutional choices is at the top of our future research agenda. 


\section{Conclusion}

Our analysis links several strains of literature in economics, law, and political science on the relationship between political institutions and policy outcomes. Our central finding is that differences in the number of elected officials in local government produce significant differences in the level of taxing and spending. With respect to non-legislative-body elected officials, adding officials to jurisdictions with few existing officials decreases spending and taxing. Adding officials to jurisdictions with lots of elected officials actually increases taxing and spending. This manifests empirically as a $U$-shaped relationship between the number of elected officials and fiscal behavior.

With respect to theoretical models of politics, our findings suggest the importance of better theorizing not just about elections writ large but also with respect to how variation in local political and institutional arrangements might facilitate or undermine the use of elections to control legislators. In this sense, our work fits into a long-standing tradition of scholarship that uses economic, demographic, and political characteristics to explore taxing and spending patterns by state and local government. However, by relying on county-level data and the nonlinear functional form, we are able to provide a novel perspective on politics, institutional structure, and public finance.

\section{References}

Alesina, Alberto, Reza Baqir, and William Easterly. 1999. Public Goods and Ethnic Divisions. Quarterly Journal of Economics 114:1243-84.

$\rightarrow$ Ashworth, Scott. 2005. Reputational Dynamics and Political Careers. Journal of Law, Economics, and Organization 21:441-66.

Ashworth, Scott, and Ethan Bueno de Mesquita. 2007. Electoral Selection, Strategic Challenger Entry, and the Incumbency Advantage. Working paper. Washington University, Department of Political Science, St. Louis.

Austen-Smith, David, and Jeffrey Banks. 1989. Electoral Accountability and Incumbency. Pp. 121-50 in Models of Strategic Choice in Politics, edited by Peter C. Ordeshook. Ann Arbor: University of Michigan Press.

Banks, Jeffrey S., and Rangarajan Sundaram. 1993. Adverse Selection and Moral Hazard in a Repeated Elections Model. Pp. 295-313 in Political Economy: Institutions, Competition, and Representation, edited by William Barnett, Melvin Hinich, and Norman Schofield. Cambridge: Cambridge University Press.

$\rightarrow$. 1998. Optimal Retention in Agency Problems. Journal of Economic Theory 82: 293-323.

$\rightarrow$ Baqir, Reza. 2002. Districting and Government Overspending. Journal of Political Economy 110:1318-54.

$\rightarrow$ Barro, Robert. 1973. The Control of Politicians: An Economic Model. Public Choice 14: 19-42.

$\rightarrow$ Beck, Nathaniel, and Simon Jackman. 1998. Beyond Linearity by Default: Generalized Additive Models. American Journal of Political Science 42:596-627.

Berry, Christopher. 2009. Imperfect Union: Representation and Taxation in Multi-Level Governments. Cambridge: Cambridge University Press. 
$\rightarrow$ Bertrand, Marianne, Esther Duflo, and Sendhil Mullainathan. 2004. How Much Should We Trust Differences-in-Differences Estimates? Quarterly Journal of Economics 119: 249-75.

$\rightarrow$ Besley, Timothy J., and Anne Case. 2003. Political Institutions and Policy Choices: Evidence from the United States. Journal of Economic Literature 41:7-73.

Besley, Timothy J., and Stephen Coate. 2001. Issue Unbundling via Citizens' Initiatives. Working Paper No. 2857. London: Centre for Economic Policy Research, London.

$\rightarrow-$. 2003. Elected Versus Appointed Regulators: Theory and Evidence. Journal of the European Economic Association 1:1176-1206.

Booms, Bernard H. 1966. City Government Form and Public Expenditure Level. National Tax Journal 19:187-99.

Campbell, Angus, Philip E. Converse, Warren E. Miller, and Donald E. Stokes. 1960. The American Voter. Chicago: University of Chicago Press.

$\rightarrow$ Clark, Terry N. 1968. Community Structure, Decision-Making, Budget Expenditures, and Urban Renewal in 51 American Communities. American Sociological Review 33:576-93.

Clark, Terry N., Lorna C. Ferguson, and Robert Y. Shapiro. 1982. Functional Performance Analysis: A New Approach to the Study of Municipal Expenditures. Political Methodology 8(fall):187-223.

Cole, Richard L. 1971. The Urban Policy Process: A Note on Structural and Regional Influences. Social Science Quarterly 52:646-55.

Cooter, Robert D. 2000. The Strategic Constitution. Princeton, N.J.: Princeton University Press.

Cutler, David M., Douglas W. Elmendorf, and Richard J. Zeckhauser. 1993. Demographic Characteristics and the Public Bundle. Public Finance 48(suppl.):178-98.

Dahl, Robert A. 1989. Democracy and Its Critics. New Haven, Conn.: Yale University Press.

$\rightarrow$ Dalenberg, Douglas R., and Kevin T. Duffy-Deno. 1991. At-Large versus Ward Elections: Implications for Public Infrastructure. Public Choice 70:335-42.

$\rightarrow$ Deno, Kevin T. and Stephen L. Mehay. 1987. Municipal Management Structure and Fiscal Performance: Do City Managers Make a Difference? Southern Economic Journal 53: 627-41.

$\rightarrow$ DeSantis, Victor S., and Tari Renner. 2002. City Government Structures: An Attempt at Clarification. State and Local Government Review 34:95-104.

$\rightarrow$ Dunne, Stephanie, Robert Reed, and James Wilbanks. 1997. Endogenizing the Median Voter: Public Choice Goes to School. Public Choice 93:99-118.

$\rightarrow$ Dye, Thomas R., and John A. Garcia. 1978. Structure, Function, and Policy in American Cities. Urban Affairs Quarterly 14:103-23.

$\rightarrow$ Epple, Dennis, and Allan Zelenitz. 1981. The Implications of Competition among Jurisdictions: Does Tiebout Need Politics? Journal of Political Economy 89:1197-1217.

$\rightarrow$ Farnham, Paul G. 1990. The Impact of Citizen Influence on Local Government Expenditure. Public Choice 64:201-12.

Fearon, James. 1999. Electoral Accountability and the Control of Politicians: Selecting Good Types versus Sanctioning Poor Performance. Pp. 55-97 in Democracy, Accountability, and Representation, edited by Adam Przeworski, Susan Stokes, and Bernard Manin. New York: Cambridge University Press.

$\rightarrow$ Ferejohn, John. 1986. Incumbent Performance and Electoral Control. Public Choice 50: 5-25.

French, P. Edward. 2004 Form of Government and Per Capita Expenditures: An Evaluation 
of Small Cities and Towns. Journal of Budgeting, Accounting, and Financial Management 16:193-209.

Gerber, Elisabeth R. 1999. The Populist Paradox: Interest Group Influence and the Promise of Direct Legislation. Princeton, N.J.: Princeton University Press.

$\rightarrow$ Gilligan, Thomas W., and John G. Matsusaka. 1995. Deviations from Constituent Interests: The Role of Legislative Structure and Political Parties in the States. Economic Inquiry 33:383-401.

$\rightarrow$ Gordon, Sanford C., Gregory A. Huber, and Dimitri Landa. 2007. Challenger Entry and Voter Learning, American Political Science Review 101:303-20.

Hastie, Trevor, and Robert Tibshirani. 1990. Generalized Additive Models. London: Chapman \& Hall.

$\rightarrow$ Hayes, Kathy, and Semoon Chang. 1990. The Relative Efficiency of City Manager and Mayorcouncil Forms of Government. Southern Economic Journal 57:167-77.

$\rightarrow$ Hines, James R., and Richard H. Thaler. 1995. The Flypaper Effect. Journal of Economic Perspectives 9(4):217-26.

$\rightarrow$ Jung, Changhoon. 2006. Forms of Government and Spending on Common Municipal Functions: A Longitudinal Approach. International Review of Administrative Sciences 72:363-76.

Knight, Brian. 2006. Common Tax Pool Problems in Federal Systems. Pp. 229-50 in Democratic Constitutional Design and Public Policy: Analysis and Evidence, edited by Roger Congleton and Brigitta Swedenborg. Cambridge, Mass.: MIT Press.

$\rightarrow$ Langbein, Laura I., Philip Crewson, and Charles N. Brasher. 1996. Rethinking Ward and At-Large Elections in Cities. Public Choice 88:275-93.

$\rightarrow$ Lineberry, Robert J., and Edmund P. Fowler. 1967 Reformism and Public Policies in American Cities. American Political Science Review 61:701-16.

$\rightarrow$ Lyons, William, and David R. Morgan. 1977. The Impact of Intergovernmental Revenue on City Expenditures: An Analysis over Time. Journal of Politics 39:1088-97.

$\rightarrow$ Maskin, Eric, and Jean Tirole. 2004. The Politician and the Judge: Accountability in Government. American Economic Review 94:1034-54.

$\rightarrow$ Matsusaka, John G. 1995. Fiscal Effects of the Voter Initiative: Evidence from the Last 30 Years. Journal of Political Economy 103:587-623.

. 2004. Direct Democracy and the Executive Branch. Unpublished manuscript. University of Southern California, Marshall School of Business, Los Angeles.

$\rightarrow$ Meltzer, Allan H., and Scott F. Richard. 1981. A Rational Theory of the Size of Government. Journal of Political Economy 89:914-27.

$\rightarrow \ldots$. 1983. Tests of a Rational Theory of the Size of Government. Public Choice 41: 403-18.

$\rightarrow$ Moe, Terry M. 2006. Political Control and the Power of the Agent. Journal of Law, Economics, and Organization 22:1-29.

$\rightarrow$ Morgan, David R., and John P. Pelissero. 1980. Urban Policy: Does Political Structure Matter? American Political Science Review 74:999-1006.

$\rightarrow$ Morgan, David R., and Sheliah S. Watson. 1995. The Effects of Mayoral Power on Urban Fiscal Policy. Policy Studies Journal 23:231-43.

Musgrave, Richard, and Alan Peacock, eds. 1958. Classics in the Theory of Public Finance. London: Macmillan.

$\rightarrow$ Nunn, Samuel. 1996. Urban Infrastructure Policies and Capital Spending in City Manager and Strong Mayor Cities. American Review of Public Administration 26:93-112. 
$\rightarrow$ Perroni, Carlo, and Kimberly A. Scharf. 2001. Tiebout with Politics: Capital Tax Competition and Constitutional Choices. Review of Economic Studies 68:133-54.

Persson, Torsten, and Guido Tabellini. 2000. Political Economics: Explaining Economic Policy. Cambridge, Mass.: MIT Press. . 2003. The Economic Effects of Constitutions. Cambridge, Mass.: MIT Press.

$\rightarrow$ Poterba, James. 1997. Demographic Structure and the Political Economy of Public Education. Journal of Policy Analysis and Management 16:48-66.

$\rightarrow$ Rauscher, Michael. 1998. Leviathan and Competition among Jurisdictions: The Case of Benefit Taxation. Journal of Urban Economics 44:59-67.

Renner, Tari. 1999. Election Processes and Minority Representation. Pp. 139-62 in Local Government Election Practices, edited by Roger L. Kemp. Jefferson, N.C.: MacFarland \& Co.

Riker, William H. 1982. Liberalism against Populism. San Francisco: W. H. Freeman.

Rose-Ackerman, Susan. 1983. Tiebout Models and the Competitive Ideal: An Essay on the Political Economy of Local Government. Pp. 23-46 in Perspectives on Local Public Finance and Public Policy, edited by J. M. Quigley. Greenwich, Conn.: JAI Press.

Schneider, Mark. 1989. The Competitive City: The Political Economy of Suburbia. Pittsburgh: University of Pittsburgh Press.

Sen, Amartya. 1983. Poverty and Famines. Oxford: Oxford University Press.

$\rightarrow$ Sherbenou, Edgar L. 1961. Class, Participation, and the Council Manager-Plan. Public Administration Review 22:131-35.

$\rightarrow$ Sonstelie, Jon C., and Paul R. Portney. 1978. Profit Maximizing Communities and the Theory of Local Public Expenditure. Journal of Urban Economics 5:263-77.

$\rightarrow$ Sprunger, Phillip, and John D. Wilson. 1998. Imperfectly Mobile Households and Durable Local Public Goods: Does the Capitalization Mechanism Work? Journal of Urban Economics 44:468-92.

$\rightarrow$ Stumm, Theodore J., and Matthew T. Corrigan. 1998. City Managers: Do They Promote Fiscal Efficiency? Journal of Urban Affairs 20:343-52.

$\rightarrow$ Taylor, Lori L. 1995. Allocative Inefficiency of Local Government. Journal of Urban Economics 37:201-11.

$\rightarrow$ Tiebout, Charles. 1956. A Pure Theory of Local Government Expenditures. Journal of Political Economy 64:416-24.

U.S. Census Bureau. 1990. Popularly Elected Officials. Volume 1, number 2, of 1987 Census of Governments. Washington, D.C.: The Bureau. - 1992. 1990 Census of Population and Housing. Washington, D.C.: Bureau of the Census.

- 1994. County and City Data Book: 1994. Washington, D.C.: The Bureau. 1995. Popularly Elected Officials. Volume 1, number 2, of 1992 Census of Governments. Washington, D.C.: The Bureau. http://www.census.gov/prod/2/gov/gc/gc92 _1_2.pdf.

$\rightarrow$ Vigdor, Jacob L. 2002. Interpreting Ethnic Fragmentation Effects. Economics Letters 75: 271-76.

$\rightarrow$ Weingast, Barry R., Kenneth Shepsle, and Christopher Johnsen. 1981. The Political Economy of Benefits and Costs: A Neoclassical Approach to Distributive Politics. Journal of Political Economy 89:642-64.

$\rightarrow$ Wilson, John. 1999. Theories of Tax Competition. National Tax Journal 52:269-304. 
Wood, Simon N. 2006. Generalized Additive Models: An Introduction with R. Boca Raton, Fla.: Champan \& Hall.

Zaller, John R. 1992. The Nature and Origins of Mass Opinion. Cambridge: Cambridge University Press. 